\title{
Theoretical Aspects of Fitness Trainer Training
}

\author{
Sergey Serper ${ }^{1},{ }^{*}$ Oleg Buranok ${ }^{1}$ \\ ${ }^{1}$ Samara State University of Social Sciences and Education, Samara, Russia \\ *Email: olegburanok@yandex.ru
}

\begin{abstract}
The article is devoted to such a complex issue as the theoretical and methodological basis for training a future trainerteacher. The topic of approaches to this problem in modern pedagogy, primarily in the framework of higher education, is considered. In addition, contradictions in contemporary higher education regarding fitness are revealed. The authors proceed from the fact that the study of the theoretical aspects of training professional fitness trainers in higher education will not only help solve the problem of students' interest in physical education and sports but will also allow a more comprehensive approach to the practical implementation of state programs of the Russian Federation to preserve the health of the nation. It is proved that a complex of closely related factors impacts the pedagogical conditions of training future trainer-teachers. The decisive factors for the introduction of a new concept for the training of trainer-teachers in the study are the interaction of state structures responsible for the implementation of educational and sports policy with private fitness centres; the interaction of fitness centres and higher education in terms of advanced training courses and master's degree programs.
\end{abstract}

Keywords: Fitness, Higher Education, Physical culture and sports, Bachelors' training, Pedagogical education, Yoga gymnastics, Theory and methodology of physical culture.

\section{INTRODUCTION}

Training trainer-teachers is one of the urgent and vital pedagogical tasks of our time and a problem at the state level. The need to preserve the health of the nation is noted in many programs, strategies and laws of the Russian Federation: "Strategy for the development of physical education and sports until 2030", the program "Education at school", "Strategy of youth policy". In addition, as noted by the President of the Russian Federation V.V. Putin: "The solution of our demographic problems and tasks depends on sports and physical education, the health of the nation depends, this is, without any exaggeration, a political task related to the prestige of the country at the international level, with the demonstration of our achievements in the field of social policy, health. It's all connected very closely and very deeply intertwined with each other" [1]. These programs and goals cannot be achieved only at one level: school or university. In the same way, in the conditions of the modern world, it is impossible to ensure the health of the nation by state programs alone. To do this, it is necessary to consolidate the efforts of both the state, higher education, and representatives of society and business.

Our research on integrating fitness elements into physical education aims to solve these problems. However, it is challenging to do this without studying the theoretical aspects of such integration. It is necessary to study the approaches existing in modern pedagogy to the use of fitness in the educational process, consider the goals and objectives that we must achieve, and analyse the main theoretical problems and questions.

\section{APPROACHES TO THE TRAINING OF TRAINER-TEACHERS}

The study was carried out in three stages: the first (2014-2016) - the choice of the topic was carried out on it, the process of analysing the degree of knowledge of the issue was started. The selection, systematisation and analysis of the primary regulatory and state documents regulating relations in fitness and the development of physical culture and sports are made. The goals and 
objectives of the future research were formulated. At the same stage, an ascertaining experiment was started. It was held among two groups (each of 100 people) of students (1st-4th year, bachelors) with two main tasks: 1) to find out the current physical condition of students and the level of formation of universal and professional competencies; 2) by questioning students to determine their expectations from the introduction of the new course "Fitness and Yoga gymnastics" into the educational process.

The second stage (2016-2018) is the formulation and refinement of the structure of the study, the correction of the content of the main stages, the study of theoretical and methodological approaches to concepts for the formation of future trainer-teachers. The main approaches are presented by both Russian and foreign researchers. Such authors as R. Pangrazi [2, p. 36], M. Lassig, K. Callan [3, 347], H. Orr [4, p. 2997 - 3000; 5, p. 531], V. Steen [6, p. 479], V. Mustonen [7, p. $4248-$ 4253] defend the position that in schools and universities, it is necessary to replace (to increase the interest of students in these classes) traditional forms of physical activity with fitness and yoga gymnastics - we will designate it as a personal approach. On the other hand, T.V. Aronova, I.A. Spitsina [8, p. 88], S.V. Ageeva, R.S. Turlubekova [9, p. 22-25], Danilova A.M., Kiseleva T.E., A.N. Krasilnikov [10, p. 29] see a dual role in fitness: both increasing students' interest in sports, and a means of forming professional competencies, if we are talking about students of pedagogical and physical education universities - this is a competence approach. Consequently, the study summarises Russian and foreign experience in implementing a wide range of approaches to fitness and reveals the principles of implementing these approaches in the context of a new model of professional training of a trainer-teacher.

The analysis of existing pedagogical programs and models was carried out: despite a relatively significant number of scientific papers on fitness and yoga gymnastics in modern pedagogy, no practical studies were found where the concept of integrating the efforts of universities and fitness centres in the process of training trainer-teachers was substantiated. In addition, at this stage, the development of a model of a fitness trainer-teacher training system has begun.

The third stage of the study (2018-2020) is verifying the developed model and the results obtained. The basic principles and elements of the training model for future trainer-teachers were adjusted. The formulation experiment has been completed. The systematisation of all the received material and conclusions was carried out.

The results of our three-stage research, as well as the analysis of scientific and methodological research, legislative acts, program documents, features of the formation and evolution of physical education, allow us to identify some contradictions:

1) at the state level: to continue economic transformations, a high level of development of the physical condition of employees is necessary, while the opportunities and conditions for achieving this level are not always feasible in practice. The requirements of the state for the implementation of physical development programs are not always reflected in the new, projected models of training specialists in physical education and sports;

2) at the educational level: between the social and state order for fitness specialists and modern bachelor's and master's degree programs in the areas of "Physical Culture and Sports" and "Pedagogical Education";

3 ) at the socio-didactic level between theoretical developments in the field of competence approach and the practice of its implementation in the field of physical education. As well as between a lot of fitness practice and a weak theoretical and methodological basis for substantiating the possibilities of implementing fitness elements into the educational process.

\section{PEDAGOGICAL CONDITIONS FOR THE PREPARATION OF A FUTURE TRAINER-TEACHER}

The contradictions identified by us made it necessary to reveal the methods of their elimination and made it possible to formulate the problem of research: in theoretical terms, this is the problem of developing the concept of teacher training for the fitness industry. In practical terms, it is a problem of designing the content and determining the methods and conditions of training a fitness teacher [11, p. 36].

Consequently, pedagogical support for the training of teachers for the fitness industry is the activity and effective interaction of all "without exception" subjects of the educational process, the content of which consists in the implementation of the designated goal, methods and techniques aimed at improving the organisational and pedagogical conditions necessary for its (purpose) achievement. The pedagogical support includes a model for training a trainer-teacher, pedagogical conditions, organisational forms and methods of teaching students, technology for guiding students' independent work, the activities of teachers implementing the constructed content of training a trainer-teacher for fitness industry.

That is why the basis for the development of the concept of training trainer-teachers for fitness should be based on the idea of the need to include a particular industrial practice from the first year of the bachelor's degree - based on fitness centres, as well as a separate course "Fitness and yoga gymnastics". The content of training trainer-teachers for the fitness industry should 
be constructed based on the content of modern physical education [12, p. 129]. This content is implemented within the framework of the activity of the teacher. Such areas of teacher's activity are:

A) educational and methodical (teaching disciplines "Fitness and yoga gymnastics", "Fundamentals of fitness", "Technologies and practices of fitness" according to the author's technology).

B) socio-pedagogical (studying the gender characteristics of students, establishing interpersonal contact, taking into account the physiological and age indicators of students).

C) correctional and developmental (conducting training, seminars, counselling, individual conversations).

D) diagnostic (observation, comparison, analysis, testing, communication).

The technology of training trainer-teachers implies the following content of the key discipline "Fitness and yoga gymnastics": Aerobics: history and modernity - 8 hours; Pilates - 8 hours; The main figures of Hatha yoga - 8 hours; General principles of yoga gymnastics - 8 hours [13, p. 92]. This course and the model developed by us as a whole cover all the years of the bachelor's degree and is also based on the knowledge and skills (in the field of physical culture and sports) acquired at previous educational levels. Coverage by a single system of all levels of education and future professional activity in physical culture and sports is one of the most important state tasks within the national health policy framework [14, p. 15].

General professional disciplines ("Theory and methodology of gymnastics", "Theory and methodology of athletics", "Adaptive physical culture", "History of physical culture", "Physiology", "Theory and methodology of physical education") play an important role in the formation of the readiness of trainer-teachers to work in the fitness industry. In the system of training of future trainer-teachers developed by us, the main emphasis in terms of content is placed on aerobics, pilates, gymnastics, stretching [15, p. 69].

\section{MODELS OF FITNESS TRAINER- TEACHER TRAINING}

The study has developed a model of bachelor's degree, master's degree, and advanced training level. The content of these models implies both their gradual passage by future trainer-teachers and one (or two) of these models, depending on the specific tasks facing the future graduate.

The conceptual model is the formation of universal competencies of Bachelor of Physical culture and sports as a fundamental element of the professional activity of a trainer-teacher.

Structural model - this model implies, first of all, the expansion and deepening of the entire complex of knowledge, skills and technologies possessed by an already established trainer-teacher. To achieve qualitatively new educational results, changes in the structure of the original model were required. This model is more suitable for the master's degree level.

Functional model - the functional model proposed by us covers all the main areas, types and elements of fitness, but to achieve new educational results within the framework of this model, the functions of its individual elements are expanded, aimed at improving not so much the professional qualities of a trainer-teacher in the field of fitness programs, but aimed at developing his pedagogical abilities as a mentor, teacher and master.

\section{CONCLUSIONS}

Summing up, I would like to note that our research has objectively proved all the main ideas laid down in its theoretical part in practice. The main theoretical aspects of training a fitness trainer-teacher were analysed:

Firstly, the main theoretical and methodological approaches to this training process are defined. We have identified a competence-based approach, in which fitness is considered by researchers, first of all, as one of the means of forming competencies; a personal approach, according to which fitness classes should activate and strengthen students' interest in sports and physical education.

Secondly, a pedagogical experiment was conducted to determine the level of students' expectations from the introduction of fitness elements into the educational process. Without this, further development of theoretical issues would be difficult.

Thirdly, the study revealed several contradictions (at the state, educational and socio-didactic level) between the theoretical requirements for training a trainerteacher and practical approaches. The theoretical and methodological base lags significantly behind both the more diverse practice (both Russian and world) and the socio-economic realities, reflected in the personnel shortage of trainer-teachers for sports centres.

Fourthly, the pedagogical conditions for the training of trainer-teachers have been studied, the main of which is the combination of theoretical fitness classes and new directions in gymnastics with the origin of practice by students based on fitness centres and sports clubs.

The theoretical significance of the work lies in the fact that for the first time, the concept of training fitness trainer-teachers was created following the Federal State 
Educational Standard 3++, the professional standard "Teacher" and the "Strategy for the development of physical culture and Sports until 2030".

The study's practical significance lies in the fact that, based on the study of the experience of regional fitness development, the author has identified a near and medium-term perspective of organisational and pedagogical fitness development. The necessity of implementing a whole range of measures aimed at the organisational side of the issue, financial, and scientifictheoretical is proved. And in each of these areas, coordinated efforts of federal, regional authorities, and private entrepreneurs are needed to fulfil the guidelines of the "Strategy for the Development of Physical Culture and Sports in the Russian Federation for the period up to $2030 "$.

The conducted research in terms of practical results allows us to correct some provisions of the theory of physical education methodology in the context of the use of new tools and methods in the framework of interaction between higher education and private sports centres to achieve the indicators that were laid down in the program documents of the President and the Government of the Russian Federation. The organisational and pedagogical conditions that ensure the effective use of fitness technologies in physical education classes in fitness centres and sports clubs, contributing to increasing the interest and motivation of students, are substantiated.

\section{AUTHOR'S CONTRIBUTION}

S.A. Serper - analysed approaches to training the fitness teachers and developed models of a new concept. O.M. Buranok - analysis of pedagogical conditions for training trainer-teachers, formulating individual conclusions.

\section{REFERENCES}

[1] "This is not entertainment": Putin on sports and doping in Russia [«Eto ne razvlekushka»: Putin o sporte i dopinge $\mathrm{v}$ Rossii]. Retrieved from: https://www.gazeta.ru/sport/2019/03/27/a_1226889 2.shtml

[2] R.P. Pangrazi, P.W. Darst, Dynamic physical education for secondary School Students. New York, 1991, 282 p.

[3] A. Ariew, R.C. Lewontin, The Confusions of Fitness // The British Journal for the Philosophy of Science 2(55) (2004) 347-363.

[4] H. Orr, Absolute Fitness, Relative Fitness, and Utility // Evolution 61(12) (2007) 2997-3000.

[5] H. Orr, Fitness and its role in evolutionary genetics // Nature Reviews Genetics 10 (2009) 531-539.
[6] W. Steen, New Ways to Look at Fitness // History and Philosophy of the Life Sciences 16(3) (1994) 479-492.

[7] V. Mustonen, Fitness Flux and Ubiquity of Adaptive Evolution // Proceedings of the National Academy of Sciences of the United States of America 107(9) (2010) 4248-4253.

[8] T.V. Aronova, I.A. Spitsina, The image of a fitness trainer as a way to optimise a professional career [Imidzh fitnes-trenera kak sposob optimizacii professional'noj kar'ery] // Theory and practice of physical culture [Teoriya i praktika fizicheskoj kul'tury] 5 (2021) 87-95.

[9] S.V. Ageeva, R.S. Turlubekova, Physical training of female students with the predominant use of fitness tools [Fizicheskaya podgotovka studentok s preimushchestvennym ispol'zovaniem sredstv fitnesa] // Bulletin of the KSPI [Vestnik KGPI] 1 (2019) 22-25.

[10] A.M. Danilova, T.E. Kiseleva, A.N. Krasilnikov, Fitness as a way to increase students' motivation for classes [Fitnes kak sposob povysheniya motivacii studentov $\mathrm{k}$ zanyatiyam] // OlymPlus. Humanitarian version [OlymPlus. Gumanitarnaya versiya] 1 (2020) 29-32.

[11] S.A. Serper, Yoga gymnastics in the formation system of general cultural competencies among future specialists in physical culture [Gimnastika jogov v sisteme formirovaniya obshchekul'turnyh kompetencij $\mathrm{u}$ budushchih specialistov po fizicheskoj kul'ture] // Bulletin of the Southern Federal University [Izvestiya YUzhnogo federal'nogo universiteta], 2017, pp. 35-40.

[12] L.V. Morozova, L.A. Kiryanova, Fitness as a means of forming models of gender behaviour and healthy lifestyle among students [Fitnes kak sredstvo formirovaniya $\mathrm{u}$ studentov modelej gendernogo povedeniya i zdorovogo obraza zhizni] // Managerial consulting [Upravlencheskoe konsul'tirovanie] 6 (2013) 128-129.

[13] D.I. Degtyareva, E.V. Turchina, Modern fitness programs [Sovremennye fitnes-programmy] // Physical education and sports training [Fizicheskoe vospitanie i sportivnaya trenirovka] 3 (2015) 9195.

[14] T.Yu. Logvina, The influence of environmental factors on the health of preschool children [Vliyanie faktorov vneshnej sredy na zdorov'e detej doshkol'nogo vozrasta] // Physical culture: upbringing, education, training [Fizicheskaya kul'tura: vospitanie, obrazovanie, trenirovka] 1 (2008) 8-15. 
[15] S.A. Serper, Fitness and general cultural competencies of future specialists in physical culture: on the role of state standards [Fitnes $\mathrm{i}$ obshchekul'turnye kompetencii budushchih specialistov po fizicheskoj kul'ture: $\mathrm{k}$ voprosu o roli gosudarstvennyh standartov] // Bulletin of the Samara Scientific Centre of the Russian Academy of Sciences: social, humanitarian, biomedical sciences [Izvestiya Samarskogo nauchnogo centra Rossijskoj akademii nauk: social'nye, gumanitarnye, mediko-biologicheskie nauki] 4 (2017) 64-69. 